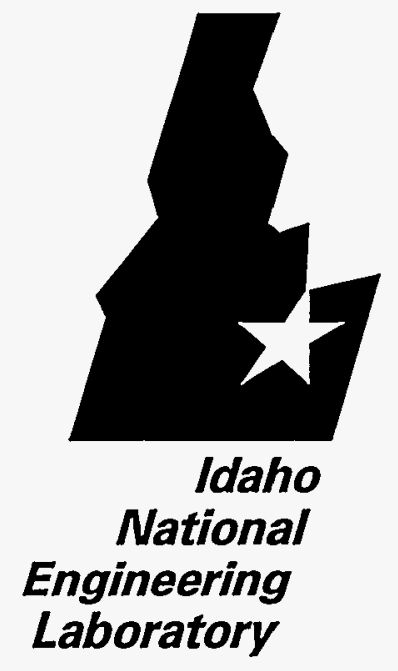

INEL-95/0114

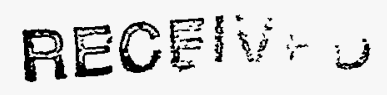

March 1995

DCT 2 \%

O TI

Catalog of Documents Produced by the Greater-Than-Class C Low-Level Waste Management Program

Michael R. Winberg

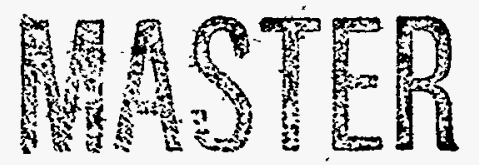

7나ockheed
Idaho Technologies company

DISTRIBUTION OF THIS DOCURAENT IS UNLWITED 


\section{DISCLAIMER}

Portions of this document may be illegible in electronic image products. Images are produced from the best available original document. 


\title{
Catalog of Documents Produced by the Greater-Than-Class C Low-Level Waste Management Program
}

Michael R. Winberg

Published March 1995

\author{
Idaho National Engineering Laboratory \\ National Low-Level Waste Management Program \\ Lockheed Idaho Technologies Company \\ Idaho Falls, Idaho 83415
}




\section{ABSTRACT}

This catalog provides a ready reference for documents prepared by the Greater-Than-Class C LowLevel Waste (GTCC LLW) Management Program. The GTCC LLW Management Program is part of the National Low-Level Waste Management Program (NLLWMP). The NLLWMP is sponsored by the U.S. Department of Energy (DOE) and is responsible for assisting the DOE in meeting its obligations under Public Law 99-240, The Low-Level Radioactive Waste Policy Amendments Act of 1985. This law assigns DOE the responsibility of ensuring the safe disposal of GTCC LLW in a facility licensed by the Nuclear Regulatory Commission (NRC). The NLLWMP is managed at the Idaho National Engineering Laboratory (INEL).

\section{DISCLAIMER}

This report was prepared as an account of work sponsored by an agency of the United States Government. Neither the United States Government nor any agency thereof, nor any of their employees, makes any warranty, express or implied, or assumes any legal liability or responsibility for the accuracy, completeness, or usefulness of any information, apparatus, product, or process disclosed, or represents that its use would not infringe privately owned rights. Reference herein to any specific commercial product, process, or service by trade name, trademark, manufacturer, or otherwise does not necessarily constitute or imply its endorsement, recommendation, or favoring by the United States Government or any agency thereof. The views and opinions of authors expressed herein do not necessarily state or reflect those of the United States Government or any agency thereof. 


\section{CONTENTS}

1. INTRODUCTION $\ldots \ldots \ldots \ldots \ldots \ldots \ldots \ldots \ldots \ldots \ldots \ldots \ldots \ldots \ldots$

2. DOCUMENTS RELATED TO THE MANAGEMENT AND STRATEGY

OF THE GTCC LLW MANAGEMENT PROGRAM $\ldots \ldots \ldots \ldots \ldots \ldots \ldots \ldots$

Reassessment of the Greater-Than Class C Low-Level Radioactive

Waste Program ......................... 3

Greater-Than-Class C Low-Level Radioactive Waste Program Reassessment . . . . . . . 5

Greater-Than-Class C Low-Level Radioactive Waste

Program 1992 Baseline Strategy $\ldots \ldots \ldots \ldots \ldots \ldots \ldots \ldots \ldots$

Managing Greater-Than-Class C Low-Level Radioactive Waste:

A Strategic Plan . . . . . . . . . . . . . . . . . . . . 9

Program Management Plan for the EG\&G Idaho Greater-Than-Class C Low-Level

Radioactive Waste Program . . . . . . . . . . . . . . . . . 11

3. DOCUMENTS RELATED TO GTCC LLW CHARACTERIZATION $\ldots \ldots \ldots \ldots$

Greater-Than-Class C Low-level Radioactive Waste

Characterization: Estimated Volumes, Radionuclide Activities, and Other Characteristics . . . . . . . . . . . . . . . . . . . 13

Evaluation of Department of Energy-Held Potential Greater-

Than-Class-C Low-Level Radioactive Waste . . . . . . . . . . . . . . . 15

Volume of Non-Fuel Bearing Components Considered Greater-

Than-Class C Low-Level Waste . . . . . . . . . . . . . . . . . . . . . . . 17

Greater-Than-Class C Low-Level Radioactive Waste

Characterization: RCRA Designation of Discarded Americium/

Beryllium Sealed Sources . . . . . . . . . . . . . . . . . . . . 1

Investigation and Analysis of Disposal Requirements for Specific DOE-Held Greater-Than-Class C Low-Level

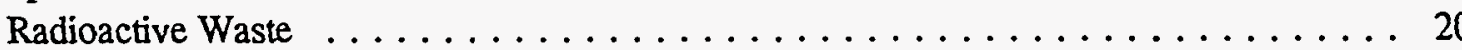


4. DOCUMENTS RELATED TO GTCC LLW PACKAGING AND

TRANSPORTATION

Greater-Than-Class C Low-Level Radioactive Waste

Transportation Strategy and Institutional Plan

Greater-Than-Class C Low-Level Radioactive Waste Shipping Package/Container

Identification and Requirements Study . . . . . . . . . . . . . . 24

Greater-Than-Class C Low-Level Radioactive Waste Transportation Regulations and

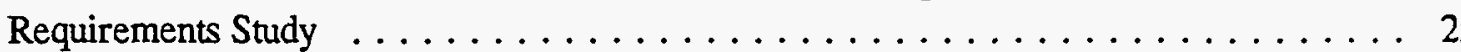

Greater-Than-Class C Low-Level Radioactive Waste Packaging and Transportation

Elements Report . . . . . . . . . . . . . . . . . . . 26

5. DOCUMENTS RELATED TO GTCC LLW STORAGE $\ldots \ldots \ldots \ldots \ldots \ldots \ldots$

Background Paper-DOE Charges for Interim Storage for Greater-Than-Class C Low-

Level Radioactive Waste . . . . . . . . . . . . . . . . . . . . . . . 29

Draft Action Plan for Coordination of GTCC LLW Interim Storage Management

Responsibilities Between EM-35 and EM-32 . . . . . . . . . . . . . 30

Preliminary Technical Position on Greater-Than-Class C Low-Level Waste Acceptance

Criteria For Long-Term Dedicated Storage Assessment . . . . . . . . . . . 31

Engineering Study-Dedicated Storage for GTCC LLW $\ldots \ldots \ldots \ldots \ldots$

Storage of Greater-Than-Class C Low-Level Waste Pending Availability of Disposal

Capacity: An Evaluation of Needs and Options . . . . . . . . . . . . . 33

Technical Survey of DOE Facilities Potentially Capable of Storing Commercially Generated Greater-Than-Class C Low-Level Waste (GTCC LLW) . . . . . . . . . . 34

Guidance for Preparation of Site-Specific Storage Acceptance Criteria for Greater-ThanClass C Low-Level Radioactive Waste ... . . . . . . . . . . . . . . . 35

Predecisional Draft-Capability for Storage of Non-DOE Greater-Than-Class C Low-Level Waste at the Idaho National Engineering Laboratory . . . . . . . . . . . . . 36

Preparation Guidance for Greater-Than-Class C Low-Level Radioactive Waste Storage Facility Design Criteria . . . . . . . . . . . . . . . . . 37 


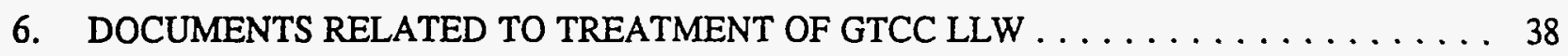

Vitrification Treatment Options for Disposal of Greater-Than-Class C Low-Level

Radioactive Waste in a Deep Geologic Repository . . . . . . . . . . . . . . . . 39

Department of Energy Treatment Capabilities for Greater-Than-Class C Low-Level

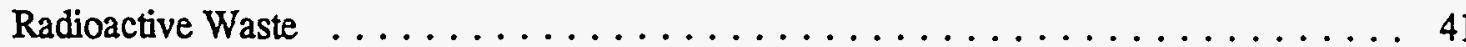

Commercial Sector Treatment Capabilities for Greater-Than-Class C Low-Level

Radioactive Waste $\ldots \ldots \ldots \ldots \ldots \ldots \ldots \ldots \ldots \ldots \ldots \ldots \ldots \ldots$

Greater-Than-Class C Low-Level Radioactive Waste Treatment Technology Evaluation . . 44

Evaluation of Treatment Technologies for Greater-Than-Class C Low-Level Radioactive

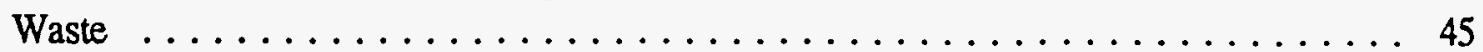

7. DOCUMENTS RELATED TO GTCC LLW FEE SPECIFICATION $\ldots \ldots \ldots \ldots$

Funding, Financial, and Accounting Issues Related to Management and Disposal of Greater-Than-Class C Low-Level Radioactive Waste . . . . . . . . . . . . . . . 47

Waste Management Facilities Cost Information Report for Greater-Than-Class $\mathrm{C}$ and DOE Equivalent Special-Case Waste . . . . . . . . . . . . . . . 48

Waste Management Facilities Cost Information Estimating Data for Greater-Than-Class C and DOE Equivalent Special-Case Waste . . . . . . . . . . . . . . . . . . 49

Proposed Fee Schedule for GTCC LLW Requiring Interim Storage . . . . . . . . . 50

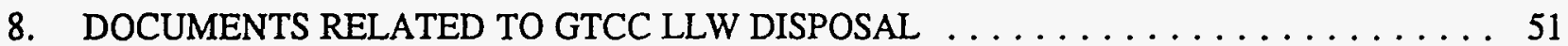

Social and Institutional Evaluation Report for Greater-Than-Class C Low-Level Radioactive Waste Disposal $\ldots \ldots \ldots \ldots \ldots \ldots \ldots \ldots \ldots \ldots \ldots \ldots \ldots$

Economics Evaluation of Technically Feasible Systems for the Disposal of Greater-ThanClass C Low-Level Radioactive Waste $\ldots \ldots \ldots \ldots \ldots \ldots \ldots \ldots$

Technically Feasible Systems for the Disposal of GTCC LLW $\ldots \ldots \ldots \ldots \ldots$

Identification of Potential Intermediate Depth and Deep Geologic Disposal Concepts for Greater-Than-Class C Low-Level Radioactive Waste . . . . . . . . . . . . . . . 56

Technical Evaluation of Near-Surface Disposal Systems for Greater-Than-Class C LowLevel Radioactive Waste-Preliminary Performance Assessment . . . . . . . . . . 58 
LLW Management Handbook: Planning for Greater Confinement Disposal, Volume II:

Appendices ............................ 59

LLW Handbook Series: Planning for Greater Confinement Disposal, Volume I:

Alternatives and Methods . . . . . . . . . . . . . . . . . . . 60

Analysis of Alternatives of Greater Confinement Disposal $\ldots \ldots \ldots \ldots \ldots \ldots$

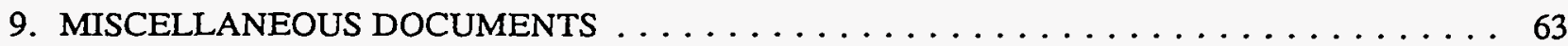

9.1 Documents Related to GTCC LLWISpecial-Case Waste . . . . . . . . . . . 63

Potential Co-Disposal of Greater-Than-Class C Low-Level Radioactive Waste with

Department of Energy Special Case Waste . . . . . . . . . . . . . . 64

Technical Survey of DOE Programs and Facilities Applicable to the Co-Storage of

Commercial GTCC LLW and DOE SCW ................... 66

Greater-Than-Class C Low-Level Radioactive Waste Special Case Wastes

(SCW) at the Idaho National Laboratory (INEL): Vol. 1: Inventory

and Characteristics ............................. 67

DOE Special Case Waste and DOE-Held Greater-Than-Class $C$ Waste at the INEL Vol.

2: Management Strategies . . . . . . . . . . . . . . . . . . 68

DOE Special Case Waste and Greater-Than-Class C Low-Level Radioactive Waste at the INEL: Vol. 3: Feasibility of Integrating Management and Disposition on a National Basis

9.2 Documents Related to GTCC LLW Sealed Sources $\ldots \ldots \ldots \ldots \ldots$

Characterization of Potential Greater-Than-Class C Sealed Sources Volume 1: Sealed Sources Held by Specific Licensees $\ldots \ldots \ldots \ldots \ldots \ldots \ldots \ldots \ldots \ldots$

Characterization of Greater-Than-Class C Sealed Sources Volume 2: Sealed Source Characterization and Future Production $\ldots \ldots \ldots \ldots \ldots \ldots \ldots \ldots \ldots$

Characterization of Greater-Than-Class C Low-Level Radioactive Waste Sealed Sources Volume 3: Sealed Sources Held by General Licensees . . . . . . . . . . . . . . . 74 


\section{Catalog of Documents Produced by the Greater-Than-Class C Low-Level Waste Management Program}

\section{INTRODUCTION}

This catalog provides a ready reference for documents prepared by the Greater-Than-Class C LowLevel Waste (GTCC LLW) Management Program. The GTCC LLW Management Program is part of the National Low-Level Waste Management Program (NLLWMP). The NLLWMP is sponsored by the U.S. Department of Energy (DOE) and is responsible for assisting the DOE in meeting its obligations under Public Law 99-240, The Low-Level Radioactive Waste Policy Amendments Act of 1985. This law assigns DOE the responsibility of ensuring the safe disposal of GTCC LLW in a facility licensed by the Nuclear Regulatory Commission (NRC). The NLLWMP is managed at the Idaho National Engineering Laboratory (INEL).

In an effort to assist the DOE in meeting its obligations, the GTCC LLW Management Program has prepared many documents. These documents can be grouped into those that are

- $\quad$ Related to GTCC LLW Management Program management and strategy

- Related to GTCC LLW characterization

- Related to GTCC LLW packaging and transportation

- $\quad$ Related to GTCC LLW storage

- Related to GTCC LLW treatment

- Related to GTCC LLW fee specification

- $\quad$ Related to GTCC LLW disposal

- Miscellaneous documents.

The documents presented in this catalog will be grouped into one of these categories. The documents will be presented in the order of the most recently produced document in that category to the oldest. Information for each document will include the title, the document number, the publication status (i.e., draft or final), a brief synopsis of the document, and a discussion of the future use and limitations of the document. 


\section{DOCUMENTS RELATED TO THE MANAGEMENT AND STRATEGY OF THE GTCC LLW MANAGEMENT PROGRAM}

The following documents are related to the management and strategy of the GTCC LLW Management Program. These documents generally set forth the plans, organizations, and systems that those responsible for managing the GTCC LLW Management Program follow. 
Topic:

Document Title:

Document Number:

Document Date:

Publication Status:
Program Management and Strategy

Reassessment of the Greater-Than Class C Low-Level Radioactive Waste Program

\section{Synopsis:}

The Low-Level Radioactive Waste Policy Amendments Act of 1985 makes the Federal government (U.S. Department of Energy) responsible for the disposal of greater-than-Class $C$ low-level radioactive waste (GTCC LLW). However, a particular approach or schedule is not prescribed in the Act.

Therefore, it is assumed that Congress has granted the U.S. Department of Energy discretion to design an approach that meets the mandate. The U.S. Department of Energy Idaho Operations Office requested the Greater-Than-Class C Low-Level Waste Management Program at EG\&G Idaho (now Lockheed Idaho Technologies Company) to conduct a qualitative reassessment of current program strategy. This document presents the assumptions, facts, recommendations, and conclusions of that qualitative reassessment.

This document reassessed the program by dividing GTCC LLW into four categories:

- Utility-Generated GTCC LLW

- $\quad$ Sealed Sources

- $\quad$ Nonutility GTCC LLW (excluding sealed sources)

- DOE-Held GTCC LLW.

The program was reassessed based on assumptions, facts, and regulatory guidance as they pertain to each of the above categories. The reassessment resulted in the following conclusions:

- Further studies, conducted by the GTCC LLW Management Program, related to treatment, transportation, storage, or disposal of utility-generated waste would be of limited value. A reasonable likelihood exists that much of this waste will become the responsibility of the DOE Office of Civilian Radioactive Waste Management (OCRWM) and will therefore be required to conform to their specific waste management systems.

- DOE should work towards co-disposing utility-generated GTCC LLW in a repository developed by the OCRWM.

- The DOE should seek congressional consideration of a separate management program for sealed sources. The program should allow for the appropriate disposition of sealed sources by DOE on a case-by-case basis. The legislation, or accompanying report language, should clarify the applicability of Federal cost-recovery practices. 
- Pending implementation of the sealed source management program, DOE should continue to accept radioactive materials, including sealed sources, from licensees in response to specific emergency incidents.

- The proposed sealed source program should be formally decoupled from DOE efforts to develop disposal capacity for GTCC LLW.

- The GTCC LLW Management Program should continue modest efforts to identify or project nonutility GTCC LLW.

- Planning for disposal of nonutility GTCC LLW in an NRC-licensed facility should be suspended until the OCRWM determines the extent of its responsibility for disposal of non-fuel bearing components under the Standard Contract.

- Once responsibility for disposal of utility-generated GTCC LLW is clarified, DOE should notify Congress of the unit costs associated with the disposal of small quantities of GTCC LLW in a special NRC-licensed facility. This will allow Congress to re-evaluate the requirement for NRC-licensed disposal of GTCC LLW.

- DOE-held GTCC LLW should be required to be disposed of in an NRC-licensed facility only if two conditions are met: The waste exceeds Class $C$ limits, and the waste would not otherwise have been accepted by DOE, but for the new responsibility in the Act.

- The Idaho National Engineering Laboratory (INEL) should be assigned the lead in coordinating and monitoring the implementation of this strategy among applicable DOE-HQ and DOE operations office elements. The INEL should continue to execute specific planning and implementation functions, as applicable.

Future use limitations and recommendations:

This document provides recommendations of the GTCC LLW Management Program on overall program strategy. Because it capsulizes lessons learned over the past seven years, it is likely to remain useful as a reference document. To date, DOE has not endorsed this report as a basis for a revised program strategy. 
Topic:

Program Management and Strategy

Document Title: $\quad$ Greater-Than-Class C Low-Level Radioactive Waste Program Reassessment

Document Number: RAE-9208/2-1 (Published under subcontract to Rogers and Associates)

Document Date: $\quad$ September 1993

Publication Status: Final Draft Report

Synopsis:

The Low-Level Radioactive Waste Policy Amendments Act of 1985, Public Law 99-240, transferred the responsibility for disposing of greater-than-Class C (GTCC) low-level radioactive waste (LLW) generated by commercial licensees from the states to the U.S. Department of Energy (DOE). The present DOE management strategy for GTCC LLW calls for developing a GTCC LLW disposal facility and storing limited amounts of GTCC LLW until the disposal facility is available.

This document identifies and evaluates alternative GTCC LLW Management Program strategies. Specific strategy options were identified that could minimize adverse impacts on cost, environment, institutional issues, and public and worker health and safety. As was expected, this reassessment showed that no single strategy was best for all of the impact criteria. Therefore, a composite strategy was recommended.

This report evaluated the following seven strategic thrusts for any specific strategy that might be selected:

- Waste acceptance criteria rulemaking

- Amending the Low-Level Radioactive Waste Policy Amendments Act

- Revising DOE/utilities standard contract for disposal of high-level waste

- Refining GTCC LLW characterization data

- Selling/recycling waste

- $\quad$ Revising 10 CFR 61 (DOE petition for rulemaking)

- $\quad$ Changing classification scheme

- Removing repository-disposal requirement

- $\quad$ Clarifying requirements for GTCC LLW waste disposal

- Nuclear Regulatory Commission (NRC) develops guidance (e.g., DOE/NRC memorandum of understanding). 
The report recommends developing waste acceptance criteria and supporting characterization technology and methodology development. The report also concludes that the NRC and DOE should develop official guidance concerning the disposal of GTCC LLW in a geologic repository and that DOE should specifically revise the standard utility contract for high-level waste disposal to include reactor internals.

Future use limitations and recommendations:

This report will be useful to assist DOE and the GTCC LLW program in developing long-term strategy for the management of GTCC LLW. To date, DOE has not endorsed the conclusions presented in this report as a basis for a revised program strategy. 
Topic:

$\begin{array}{ll}\text { Document Title: } & \text { Greater-Than-Class C Low-Level Radioactive Waste Program } 1992 \text { Baseline } \\ \text { Strategy }\end{array}$

Document Number: DOE/LLW-172

Document Date: February 1993

Publication Status: Formal Report (Final Draft)

\section{Synopsis:}

This baseline strategy document describes Department of Energy (DOE) goals, objectives, and strategy for fulfilling its responsibility to dispose of greater-than-Class C low-level waste (GTCC LLW) according to the requirements of Section 3(b) of the Low-Level Radioactive Waste Policy Amendments Act of 1985, Public Law 99-240. This document describes the baseline strategy being employed at the end of FY 1992. The strategy for fulfilling the above responsibility consists of three tasks:

- Interim storage of limited quantities of GTCC LLW at a currently operating DOE facility to eliminate a potential public health and safety threat

- Acceptance of GTCC LLW for storage in a DOE dedicated facility on an as-needed basis pending disposal

- Disposal in a facility licensed by the Nuclear Regulatory Commission (NRC).

The objective of the interim storage task is to establish a program to accept limited amounts of GTCC LLW for storage before disposal capability is available, beginning in 1994. Acceptance of waste will be limited to GTCC LLW that represents a threat to public health and safety, as determined by the appropriate regulatory authority. Wastes will remain in interim storage until a dedicated storage or disposal facility is available.

The objective of the dedicated storage task is to provide long-term storage of GTCC LLW until disposal capacity is available. Dedicated storage will be provided on as-needed basis, until disposal capabilities are available, for the GTCC LLW that generators are unable to safely store.

The objective of the disposal task is to provide for GTCC LLW disposal in an NRC-licensed facility.

The interim storage, dedicated storage, and disposal facility development will be supported by treatment, packaging, and transportation tasks. In addition, a fee methodology will be established to ensure that fees assessed by DOE for acceptance of GTCC LLW reflect the most current information regarding the costs associated with these activities.

This plan includes a summary chart of key milestones and major decision points for implementing the baseline strategy. 


\section{Future use limitations and recommendations:}

Since this document was published, the GTCC LLW Management Program has undergone a reassessment; this strategy document was the baseline point for the reassessment. The tasks and planning described in this report are no longer being implemented as described. However, many of the reports associated with these tasks in the areas of treatment, packaging, fee specification, and storage and disposal options have been completed and are described in other areas of this catalog. 
Topic:

Document Title: Managing Greater-Than-Class C Low-Level Radioactive Waste: A Strategic Plan

Document Number: DOE/LLW-79T

Document Date: $\quad$ August 1990

Publication Status: Formal Report (Predecisional Draft)

Program Management and Strategy

Synopsis:

This strategic plan describes the Department of Energy (DOE) goals, objectives, and strategy for fulfilling its responsibility to dispose of greater-than-Class C low-level radioactive waste (GTCC LLW), in accordance with the requirements of Section 3(b) of the Low-Level Radioactive Waste Policy Amendments Act of 1985, Public Law 99-240.

The strategy for fulfilling the above responsibility consists of three tasks:

- Interim storage of limited quantities of GTCC LLW at a currently operating DOE facility to eliminate a potential public health and safety threat

- Acceptance of GTCC LLW for storage in a DOE dedicated facility on an as-needed basis pending disposal

- GTCC LLW disposal in a facility licensed by the Nuclear Regulatory Commission.

The objective of the interim storage task is to establish a program to accept limited amounts of GTCC LLW for storage before disposal capability is available, beginning in 1994. Acceptance of waste will be limited to GTCC LLW that represents a threat to public health and safety, as determined by the appropriate regulatory authority. Wastes will remain in interim storage until a dedicated storage or disposal facility is available.

The objective of the dedicated storage task is to provide long-term storage of GTCC LLW until disposal capacity is available. Dedicated storage will be provided on as-needed basis, until disposal capabilities are available, to generators of GTCC LLW that are unable to safely store their GTCC LLW.

The objective of the disposal task is to provide for GTCC LLW disposal in an NRC-licensed facility.

The interim storage, dedicated storage, and disposal facility development will be supported by treatment, packaging, and transportation tasks. In addition, a fee methodology will be established to ensure that fees assessed by DOE for acceptance of GTCC LLW reflect the most current information regarding the costs associated with these activities.

This plan includes a summary chart of key milestones and major decision points for implementing the baseline strategy. 
Future use limitations and recommendations:

This report was replaced by the report DOElLLW-172; several draft strategy revisions were prepared during the intervening period. The management plans, schedules, and milestones described in this report are no longer current. 
Topic:

Document Title:

Program Management and Strategy

Program Management Plan for the EG\&G Idaho Greater-Than-Class C Low-Level Radioactive Waste Program

Document Number: EGG-LLW-9877

Document Date: September 1991

Publication Status: Informal Report (Final)

Synopsis:

The Program Management Plan for the EG\&G Idaho Greater-Than-Class C Low-Level Waste (GTCC LLW) Management Program sets forth the plans, organizations, and systems that those responsible for managing the GTCC LLW Management Program follow.

This document includes information on program control and project management. It describes the management organization and responsibilities, a work plan, a work breakdown structure, a schedule, and performance criteria for the GTCC LLW Management Program.

This document provided the basic strategy that was detailed in later program management documents to include the tasks of interim storage, dedicated storage, and final disposal.

\section{Future use limitations and recommendations:}

The information in this document is obsolete. It is useful only as historical reference detailing the development of the GTCC LLW Management Program strategy. The GTCC LLW Management Program was subsequently covered under broader program management plans that included other National LowLevel Waste Management Program activities. 


\section{DOCUMENTS RELATED TO GTCC LLW CHARACTERIZATION}

This section of the catalog lists documents related to the characterization of GTCC LLW. Information related to characterization includes identification of possible waste streams, waste forms, estimated volumes, and radionuclide activities. This type of information is needed in order to develop proper plans for treating, packaging, storing, and disposing of GTCC LLW. 
Topic:

Document Title: Greater-Than-Class C Low-level Radioactive Waste Characterization: Estimated Volumes, Radionuclide Activities, and Other Characteristics

Document Number: DOEILLW-114

Document Date: $\quad$ Revision 0 published September 1991

Revision 1 published September 1994

Publication Status: Formal Report (Final)

Synopsis:

The purpose of this report is to estimate present and future greater-than-Class $\mathrm{C}$ low-level waste (GTCC LLW) volumes, radionuclide activities, and waste forms, and to identify potential waste generators. These estimates are necessary in order to assist in developing long-term strategic planning for storage, treatment, fee assessment, and final disposal of GTCC LLW. The Department of Energy (DOE) is responsible for the disposition of GTCC LLW. The estimates in this report represent the best available data for DOE's planning for this disposition.

The 1994 report is an update of a 1991 document of the same title, hereafter referred to as Revision 0 . Revision 0 evaluated potential GTCC LLW generators to estimate future generation rates and resulting volumes. Revision 1 incorporates information from additional studies performed since Revision 0 was published in 1991.

For discussion in this report, GTCC LLW is divided into four categories. Each category is determined by the major industry that produces the waste or agency that is currently holding it. These categories are

- Nuclear Utilities

- $\quad$ Sealed Sources

- DOE-Held

- $\quad$ Other Generators.

Nuclear utility waste consists of activated metals and process wastes generated by commercial nuclear power plants. GTCC sealed sources (with activities exceeding Class $\mathrm{C}$ limits) consist of radioactive materials used in measurement devices or for calibration. DOE-Held waste consists of several commercial radioactive materials that (a) exceed Class $C$ limits, and (b) DOE has accepted for various reasons (e.g., research and development, contractual obligations, public health and safety, etc.). Other Generator waste consists of sludge, activated metals, and other wastes that are generated by radionuclide manufacturers, university and commercial research reactors, sealed source manufacturers, and similar types of operations. 
Revision 1 estimated the 1993 GTCC LLW volumes for all categories. In addition, future volumes were estimated to the year 2035 for the sealed sources and other generator categories, and to the year 2055 for the nuclear utility category. The year 2055 is the assumed date when most of the currently operating reactors will have ended operation. Unpackaged and packaged volumes were estimated for each category of GTCC LLW. The effects of concentration averaging practices used by commercial LLW generators were also considered in estimating the GTCC LLW packaged volumes. In addition, a range of these estimates was made by varying the timing, packaging, and concentration averaging assumptions. This resulted in low, base, and high case volume projections.

This report concluded that the total future projected volume of GTCC LLW will not be large enough to warrant construction of a dedicated disposal facility. The total volume of GTCC LLW is manageable using current technology and management strategies.

The report contains appendix documents. These appendix documents contain information and data used to make the volume and activity projections contained in the main body of the report. The following appendix documents are part of this report:

Appendix A-2: Timing of GTCC LLW from Nuclear Power Plants

Appendix D-3: Characterization of GTCC LLW from Other Generators

Appendix E-2: Mixed GTCC LLW Assessment

Appendix E-4: Packaging Factors for GTCC LLW

Appendix E-5: Impact of the 1993 draft NRC Branch Technical Position on Concentration Averaging of GTCC LLW

Future use limitations and recommendations:

The 1994 version of the report contains the best data available to assist DOE and the GTCC LLW Management Program in developing strategy and plans for the ultimate disposal of GTCC LLW. The initial 1991 version is now of only historical interest. 
Topic:

GTCC LLW Charactcrization

Document Title: Evaluation of Department of Energy-Held Potential Greater-Than-Class-C LowLevel Radioactive Waste

Document Number: DOELLW-147

Document Date: $\quad$ September 1994

Publication Status: Formal Report (Final Draft)

Synopsis:

A number of commercial facilities have generated potential greater-than-Class $C$ low-level waste (GTCC LLW). Through contractual arrangements with the Department of Energy (DOE) and/or for health and safety reasons, the waste is stored at DOE facilities. This document is an evaluation of this DOE-Held potential GTCC LLW to determine if it requires management and disposal under Public Law (PL) 99-240, which requires that DOE ensure the safe disposal of GTCC LLW in a Nuclear Regulatory Commission (NRC) licensed facility.

This document identifies each of the commercial potential GTCC LLWs currently stored at DOE facilities. It describes the physical form volume, and radionuclide content of the waste, and gives a summary of the legal and contractual arrangements and history associated with DOE acceptance of these wastes for storage.

As part of this document, the GTCC LLW Management Program developed a decision process to evaluate the legal and contractual arrangements by which DOE accepts waste for storage. That process was developed to assist the GTCC LLW Management Program in deciding which of the potential GTCC LLW forms identified in this document would be classified and managed as GTCC LLW under PL 99-240. That decision process includes the following questions:

- Is the waste owned by DOE under PL $99-240$, or is DOE responsible for it under the Atomic Energy Act?

- Does the waste exceed the Class $\mathrm{C}$ limits as defined in 10 CFR 61.55, Tables 1 and 2 ?

- Is the waste generated by a NRC or Agreement State licensee?

- Is management of the waste under PL 99-240 required?

The decision process concludes that, under the contractual agreements and circumstances under which the wastes were accepted for storage, only one of the wastes identified as DOE-held potential GTCC LLW in this document might fall under the requirements of PL 99-240. The other wastes should not require NRClicensed disposal. Insufficient data and information were available to evaluate the West Valley waste at this time. The management requirements for West Valley waste will be assessed at a later date. 


\section{Future use limitations and recommendations:}

The validity of the conclusions in this report are dependent on obtaining DOE-HQ legal counsel concurrence with the decision process used to make the determinations detailed in this document. At the time of publication of this catalog (March 1995), that concurrence has not been obtained. If the DOE-HQ legal counsel fails to give concurrence, it will be necessary to re-evaluate the determinations made in this report. 
Topic:

Document Title: Volume ofNon-Fuel Bearing Components Considered Greater-Than-Class C LowLevel Waste

Document Number: DOELLW-167

Document Date: February 1993

Publication Status: Formal Report (Draft)

Synopsis:

This document addresses non-fuel bearing reactor components in order to estimate the volume that may require management under the GTCC LLW Management Program through the year 2035. This document discusses these wastes as they relate to the Standard Contract (10 CFR 961) in determining which non-fuel bearing components may have to be managed as GTCC LLW. All non-fuel components that are covered under the Standard Contract are eligible for disposal as high-level waste (HLW) in the HLW repository. Non-fuel components included in the Standard Contract will not require management as GTCC LLW.

The approach used in the document was to identify and exclude all non-fuel components that are listed or implied under the Standard Contract; the remaining components may require management as GTCC LLW. This report assumes that the following non-fuel components may not be included in the Standard Contract and may therefore have to be managed as GTCC LLW:

- BWR control rod blades

- IRM/SRM dry tubes

- Instrument strings.

The data in the document indicate that the estimated GTCC LLW non-fuel bearing components volume will range between $0 \mathrm{~m}^{3}$ and $559 \mathrm{~m}^{3}$. The document identified several areas of uncertainty that may affect the total volume, such as:

- Interpretation of the Standard Contract

- Availability and cost of storage at generator facility

- Continuation of concentration averaging practices

- Availability of HLW disposal

- Availability of GTCC LLW disposal. 
Future use limitations and recommendations:

This document is useful for calling attention to the fact that the interpretation of the Standard Contract in relation to non-fuel bearing components will have a significant impact on the total volume of GTCC LLW that must be managed in the future. 
Topic:

Document Title: Greater-Than-Class C Low-Level Radioactive Waste Characterization: RCRA Designation of Discarded Americium/Beryllium Sealed Sources

Document Number: DOELLLW-195

Document Date: November 1993

Publication Status: Formal Report (Final)

\section{Synopsis:}

The purpose of this document is to evaluate the hazardous classification of discarded americium/beryllium sources. These sources were evaluated according to the 40 CFR 261 criteria to determine if these sources are to be classified as a mixed radioactive/hazardous waste.

It was determined that discarded amcricium/beryllium sources do not contain any wastes listed in Subpart D of 40 CFR 261, nor do they exhibit any hazardous characteristics. Therefore, these sources are not a mixed waste under the regulations established by the U.S. Environmental Protection Agency.

Future use limitations and recommendations:

It is important to note that hazardous waste regulations that are part of state regulatory programs may differ from Federal government regulations. Therefore, the determinations in this report should be evaluated according to state criteria if used to determine if sources can be disposed of in a regulated disposal facility by a state or compact. 
Topic:

Document Title: Investigation and Analysis of Disposal Requirements for Specific DOE-Held Greater-Than-Class C Low-Level Radioactive Waste

Document Number:

Document Date: $\quad$ April 1993

Publication Status: Draft Report

GTCC LLW Charactcrization

\section{DOELLW-174}

Synopsis:

This document details the investigation of the disposal requirements for several specific commercial wastes accepted by DOE for storage. These wastes include:

- The Mexican americium waste

- $\quad$ The West Valley waste

- The Surry 2 and Turkey Point 3 waste.

These wastes were investigated to determine the legal and contractual agreements under which these wastes were accepted for disposal in order to determine if they will require management as GTCC LLW under Public Law 99-240 and disposal in a facility licensed by the Nuclear Regulatory Commission (NRC).

A preliminary determination was made that the Mexican americium and Surry 2 and Turkey Point 3 wastes will not require disposal in an NRC-licensed facility. Since detailed characterization of the West Valley waste was unavailable, the final disposition of this waste is undetermined.

Future use limitations and recommendations:

This report was never published in final form. The information in this report was updated and combined with the information and data contained in the document DOELLW-147, which is also described in this catalog. 


\section{DOCUMENTS RELATED TO GTCC LLW PACKAGING AND TRANSPORTATION}

This section of the catalog describes documents related to packaging and transporting GTCC LLW. Documents in this section describe the requirements and related studies that detail issues and technology related to packaging and transporting GTCC LLW. 
Topic:

Document Title: Greater-Than-Class C Low-Level Radioactive Waste Transportation Strategy and Institutional Plan

Document Number: DOELLW-192

Document Date: September 1993

Publication Status: Formal Report

\section{Synopsis:}

This document contains two parts. Part I, "Greater-Than-Class C Low-Level Radioactive Waste Transportation Strategy," addresses the requircments, responsibilities, and strategy to implement the requirements to transport and receive these wastes. The strategy covers:

- Transportation packaging, which includes shipping casks and waste containers

- Transportation operations, relating to the five facilities involved in transportation (waste originator, interim storage, dedicated storage, treatment, and disposal)

- System safety and risk analysis

- Routes

- Emergency preparedness and response

- Safeguards and security.

Part II, "Institutional Plan for the GTCC LLW Management Program," addresses the assumptions, requirements, and institutional plans, elements, and actions. As the plans make clear, the most challenging issues facing the GTCC LLW Management Program shipping campaign are institutional issues closely related to the strategy. The following are clements of the institutional plan:

- ProgramlProject Plan

- Public Information Planning and Coordination

- Environmental Compliance Documentation

- Shipment Policy and Procedures

- State, Local, and Tribal Interaction

- Emergency Response 
- Transport Plan.

How the Program addresses those issues and demonstrates to the states, local governments, and private citizens that the shipments will be made safely will strongly affect the success of the campaign.

Future use limitations and recommendations:

This document recommends that planning action related to a transportation campaign be subject to review on a regular basis as developments unfold in the United States. 
Topic:

Document Title: Greater-Than-Class C Low-Level Radioactive Waste Shipping Package/Container Identification and Requirements Study

Document Number: DOELLW-184

Document Date: August 1993

Publication Status: Formal Report (Final)

Synopsis:

This document identifies a variety of shipping packages (also referred to as casks) and waste containers currently available or being developed that could be used for greater-than-Class C (GTCC) low-level waste (LLW).

This document discusses the types of GTCC LLW forms that require packaging, discusses cask and container shipping requirements, the current available shipping casks and containers, and identifies areas that will require further guidance from the Department of Energy (DOE) related to GTCC LLW packaging and transportation.

The conclusions in this document indicatc a wide variety of shipping packages and waste containers that could be used to transport GTCC LLW. Unless acceptance criteria are developed for GTCC LLW accepted by DOE, the potential exists for receiving a wide variety of containers transported in various shipping packages.

This document does not try to identify the "best" package or container(s); however, several shipping packages and containers that have attributes that make them desirable for handling GTCC LLW are identified in this document.

Future use limitations and recommendations:

This document should provide a useful reference when further packaging and transportation issues are identified by the program. 
Topic:

Document Title: Greater-Than-Class $C$ Low-Level Radioactive Waste Transportation Regulations and Requirements Study

Document Number: DOELLW-178

Document Date: July 1993

Publication Status: Formal Report (Final)

Synopsis:

This document identifies the regulations and requirements for transporting greater-than-Class $\mathrm{C}$ (GTCC) low-level waste (LLW) and the planning activities that need to be accomplished in preparation for transporting GTCC LLW.

This document identifies the Federal, state, local government, and Indian Tribes transportation regulations and requirements for GTCC LLW. In addition, this document identifies the planning activities needed to ensure that all GTCC LLW transportation activities comply with the regulations and requirements. These planning activities include:

- Transportation packaging

- Transportation operations

- System safety and risk analysis

- Route selection

- Emergency preparedness and response

- Safeguards and security.

The conclusions in this document indicate that transporting GTCC LLW will involve a complex maze of regulations and requirements dictated by several Federal agencies, state and local governments, and Indian tribes. This document identifies the major requirements and planning activities required to ensure a GTCC shipping campaign with minimal issues.

Future use limitations and recommendations:

This document should provide a useful rcference for shipping GTCC LLW to a DOE storage or disposal facility. 
Topic: $\quad$ GTCC LLW Packaging and Transportation

Document Title: $\quad$ Greater-Than-Class C Low-Level Radioactive Waste Packaging and Transportation Elements Report

Document Number: DOELLW-116

Document Date: October 1991

Publication Status: Formal Report (Final)

\section{Synopsis:}

This report discusses those elements that will be necessary to ensure a comprehensive packaging and transportation system. The report also provides recommendations of future activities required to further develop each element of a packaging and transportation system and to integrate transportation into the overall objectives of the Greater-Than-Class C Low-Level Waste (GTCC LLW) Management Program.

Packaging and transportation elements discussed in this document include:

- Program background and roles of participants

- Waste generators and waste forms

- Transportation packaging (casks)

- Waste containers and handling sy'stems

- System safety and risk analysis

- Quality assurance

- Regulatory compliance

- Operations

- Safeguards and security

- Emergency preparedness

- Program management.

This document identifies the tasks required to complete preparations for the transportation of GTCC LLW. They include detailed project management and planning; determination of cost and schedule; detailed identification of quality assurance and regulatory requirements; and establishing waste acceptance and packaging requirements. 
Future use limitations and recommendations:

The document was the first step in preparing for the packaging and transportation of GTCC LLW. Other documents listed in this section of the catalog are based on the planning described in this document. 


\section{DOCUMENTS RELATED TO GTCC LLW STORAGE}

This section of the catalog describes documents related to the storage of GTCC LLW. Documents in this section describe the requirements for, and studies related to, interim and long-term storage of GTCC LLW. 
Topic:

Document Title: $\quad$ Background Paper-DOE Charges for Interim Storage for Greater-Than-Class $C$ Low-Level Radioactive Waste

Document Number: RLS-41-93 (transmittal letter number)

Document Date: $\quad$ February 1993

Publication Status: Letter Report

This letter report contains the following items:

- Action Decision Memorandum for the GTCC LLW Interim Storage Program

- Preliminary Draft Federal Register Notice-"Terms and Conditions for Acceptance of GTCC LLW for Interim Storage"

- Background Paper-DOE Charges for Interim Storage for Greater-Than-Class C Low-Level Radioactive Waste.

Future use limitations and recommendations:

The Action Decision Memorandum for GTCC LLW was not submitted to, or approved by, DOE/EM management at DOE-HQ. Similarly, the draft Federal Register notice was never published. Several Draft revisions to this material were made. This information has historical information on the approach to establishing terms, conditions, and fees for GTCC LLW acceptance by DOE. 
Topic:

GTCC LLW Storage

Document Title: $\quad$ Draft Action Plan for Coordination of GTCC LLW Interim Storage Management Responsibilities Between EM-35 and EM-32.

Document Number: RLS-275-92 (transmittal letter number)

Document Date: $\quad$ September 1992

Publication Status: Letter Report

Synopsis:

This letter report contains a draft action plan in response to a request from Joseph A. Coleman of U.S. Department of Energy (DOE) Headquarters. The purpose of this plan is to coordinate planning, define responsibilities, and provide a detailed list of activities, descriptions, and sequences for the greater-than-Class $C$ low-level radioactive waste interim storage task that will be turned over from DOE Division of Technical Support (EM-35) to the DOE Division of Waste Operations (EM-32).

Future use limitations and recommendations:

The scope of interim storage and the DOE-HQ organization have both changed since this letter report was prepared. Nevertheless, the report continues to have value in identifying specific tasks needed to establish and transition to interim storage in a operational phase. 
Topic:

Document Title: $\quad$ Preliminary Technical Position on Greater-Than-Class C Low-Level Waste Acceptance Criteria For Long-Term Dedicated Storage Assessment

Document Number: $\quad$ DOE/LLW-142

Document Date: $\quad$ March 1992

Publication Status: Formal Report (Final)

GTCC LLW Storage

Synopsis:

This preliminary technical position report was developed to provide criteria to support a functional and operating requirements document that will be used to design and construct a long-term dedicated storage facility for greater-than-Class C low-level waste (GTCC LLW). This technical position also defines the criteria that the generators must meet in preparing GTCC LLW for long-term storage.

The criteria are issued as a technical position report to allow the criteria to evolve as the GTCC LLW program matures and to support engineering studies being developed by the National Low-Level Waste Management Program.

The waste acceptance criteria in this report represent a compilation of Federal regulations, U.S. Department of Energy orders, and other rules, regulations, standards, and guidelines to manage GTCC LLW as defined in 10 CFR 61.55. The primary bases for the criteria are the waste acceptance criteria developed for the disposal of transuranic waste at the Waste Isolation Pilot Plant (WIPP) in New Mexico.

\section{Future use limitations and recommendations:}

Future use of this document is not anticipated. The criteria would not necessarily apply to GTCC LLW disposal unless such disposal would take place at WIPP (an unlikely scenario). These criteria do not apply to storage. 
Topic:

GTCC LLW Storage

Document Title: $\quad$ Engineering Study-Dedicated Storage for GTCC LLW

Document Number: DOELLW-143

Document Date: $\quad$ February 1992

Publication Status: Formal Report (Draft)

Synopsis:

This study evaluates the problem of providing storage for greater-than-Class $\mathrm{C}$ low-level radioactive waste until a disposal option is available that satisfies the requirements of 10 CFR 61. Until a long-term dedicated storage system is available, DOE has made separate arrangements to accept GTCC LLW on a caseby-case basis to avoid any negative impacts to the public or the environment and health and safety of the public.

Future use limitations and recommendations:

This document is an unreviewed compilation of working papers that is of historical interest only. 
Topic:

Document Title: $\quad$ Storage of Greater-Than-Class C Low-Level Waste Pending Availability of Disposal Capacity: An Evaluation of Needs and Options

Document Number: DOE/LLW-89T

Document Date: August 1990

Publication Status: Formal Report (Final Draft)

Synopsis:

This report evaluates the need for storage of greater-than-Class C low-level waste (GTCC LLW) until disposal facilities are available, and explores the options available for such storage. The possibilities of onsite storage by the generator versus the advantages of collective storage are discussed. These discussions are based on review of available data and on projections of the amount of GTCC LLW that will require storage between the years 1996 and 2010.

The report examines the possibility of either private or Department of Energy (DOE) development of collective storage and discusses the impacts of active regulatory encouragement of collective storage. The report recommends that collective storage of GTCC LLW should be established. It is additionally recommended that private development of a collective storage facility should be solicited and that private development at a Federal site and Federal sharing. of financial risk should be considered, if necessary to ensure feasibility for private development. If private development is not feasible, DOE should develop a collective storage facility.

Future use limitations and recommendations:

This report is a useful reference concerning the evolution of the strategy for storage of GTCC LLW. 
Topic:

GTCC LLW Storage

Document Title: $\quad$ Technical Survey of DOE Facilities Potentially Capable of Storing Commercially Generated Greater-Than-Class C Low-Level Waste (GTCC LLW)

Document Number: DOE/LLW-90T

Document Date: $\quad$ December 1989

Publication Status: Formal Report (Final)

Synopsis:

This report identifies and assesses those Department of Energy (DOE) facilities that are physically capable of providing, and that meet the regulatory requirements for providing, interim storage for a limited quantity of commercially generated greater-than-Class C low-level waste (GTCC LLW). The basis for this report is information provided by six DOE Operations Offices and their contractors in response to a questionnaire and site visits. The report examines existing DOE waste management facilities potentially capable of providing storage. Key considerations in performing this study were to identify those facilities that would require minimal modifications, both physical and regulatory, in order to accept the GTCC LLW. These considerations were necessary because DOE planned to have interim storage capabilities available at existing DOE facilities for limited volumes of GTCC LLW by mid-1990. This survey provides a technical basis for DOE's selection of an interim storage facility (facilities) for limited volumes of GTCC LLW.

The survey detailed in this document indicates that facilities capable of handling all GTCC LLW forms, at minimal additional cost, currently exist within the DOE system.

Future use limitations and recommendations:

The information in this document will provide a useful reference to identify DOE facilities capable of storing GTCC LLW. 
Topic:

Document Title: . Guidance for Preparation of Site-Specific Storage Acceptance Criteria for Greater-Than-Class C Low-Level Radioactive Waste

Document Number: DOELLLW-70T

Document Date: $\quad$ March 1989

Publication Status: Formal Report (Final)

Synopsis:

This document identifies the concerns and generic requirements that must be addressed when preparing low-level radioactive waste criteria for acceptance of greater-than-Class C (GTCC) low-level waste (LLW) for storage at a DOE waste management facility. It provides a baseline from which waste acceptance criteria, specific to a given storage facility, can be developed. include:

The generic requirements that must be identified in preparing site-specific storage acceptance criteria

- Waste containers

- Waste packages

- Waste material requirements

- Documentation

- Quality assurance.

Future use limitations and recommendations:

The detailed information on the gencric requirements in this document should provide a useful reference when, or if, interim storage for GTCC LLW is needed. 
Topic:

Document Title: $\quad$ Predecisional Draft-Capability for Storage of Non-DOE Greater-Than-Class C Low-Level Waste at the Idaho National Engineering Laboratory

Document Number: WM-NE-89-001

Document Date: $\quad$ March 1989

Publication Status: Informal Report (Final)

Synopsis:

This document briefly describes the Idaho National Engineering Laboratory and its major facilities. Four of those facilities having suitable capabilities are described in greater detail and given further consideration. The four facilities are: (1) the Radioactive Waste Management Complex (RWMC), (2) the Test Area North (TAN), (3) the Power Burst Facility (PBF), and (4) the Idaho Chemical Processing Plant. Of those facilities, the RWMC and TAN were found to offer the most suitable capability for managing GTCC LLW, before disposal. The RWMC affords greater storage capacity, while TAN has greater capability for handling, examining, and repackaging radioactive waste packages.

\section{Future use limitations and recommendations:}

The facilities considered in this report may no longer be optimum because of changes is mission. Also, the GTCC LLW Program strategy no longer recognizes a strong need for general acceptance of GTCC LLW for pre-disposal storage. 
Topic:

GTCC LLW Storage

Document Title: $\quad$ Preparation Guidance for Greater-Than-Class C Low-Level Radioactive Waste Storage Facility Design Criteria

Document Number: EGG-LLW-8263

Document Date: $\quad$ September 1988

Publication Status: Informal Report (Draft)

Synopsis:

This document identifies the greater-than-Class C low-level waste (GTCC LLW) storage facility capabilities and generic requirements for the design of a safe, operable, and practical facility. It provides a baseline from which a specific facility design criteria document may be developed. Neither the Nuclear Regulatory Commission (NRC) nor the Department of Energy (DOE) has regulations specifically addressing GTCC low-level waste (LLW); therefore, the guidance given in this document is based on the intent of the published NRC and DOE requirements for other radioactive wastes.

The following requirements are addressed in this document:

- Functional capabilities of a GTCC LLW storage facility

- Codes, specifications, DOE orders, and Federal regulations

- Requirements

- Natural phenomena

- Facility operational requirements

- Decommissioning

- Ancillary requirements.

Future use limitations and recommendations:

The detailed information on the generic requirements in this document should provide a useful reference when, or if, interim storage for GTCC LLW is needed. It should be noted that since this document was published, there may have been changes or additions to the applicable laws, orders, and regulations that are described in the document. 


\section{DOCUMENTS RELATED TO TREATMENT OF GTCC LLW}

The documents in this section of the catalog contain information and studies conducted relative to the options for treating GTCC LLW. 
Topic:

GTCC LLW Treatment

Document Title: Vitrification Treatment Options for Disposal of Greater-Than-Class C Low-Level Radioactive Waste in a Deep Geologic Repository

Document Number: DOELLLW-210

Document Date: $\quad$ October 1994

Publication Status: Formal Report (Draft)

\section{Synopsis:}

The Department of Energy (DOE), in keeping with its responsibility under Public Law 99-240, "The Low-Level Radioactive Waste Policy Amendments Act of 1985," is investigating several options for disposal of greater-than-Class C low-level waste (GTCC LLW), including emplacement in a deep geologic repository. At this time, vitrification (namely borosilicate glass) is the standard waste form assumed for high-level waste accepted into the Office of Civilian Radioactive Waste Management System. This report supports DOE's investigation of the deep geologic disposal option by comparing vitrification treatments that can convert GTCC LLW forms that are migratory in nature into stable waste forms acceptable for deep geologic disposal.

This document identifies eight different vitrification techniques that use glass, glass ceramic, or basalt waste form matrices. Six of these techniques are discussed in detail and include:

- Borosilicate glass

- Aluminosilicate glass

- Pyrex glass

- Phosphate glass

- $\quad$ Glass ceramic

- Iron-enriched basalt.

The information in this document indicates that GTCC LLW could be vitrified using any of the techniques described in this report. This report does not select a "best" method; however, the Iron Enriched Basalt-4 process using a plasma arc melter appears to be the most versatile in immobilizing the greatest variety of GTCC LLW. Organic wastes (except those containing ${ }^{14} \mathrm{C}$ ) should be incinerated as a pretreatment for vitrification. This reduces the gas generated in the melter, which is caused by the transport of volatile organics out of the melt. 
Future use limitations and recommendations:

It is possible that vitrification is not the best choice for treating GTCC LLW for disposal. When disposal requirements for GTCC LLW are known, the treatment options should be revisited. 
Topic:

Document Title:

Department of Energy Treatment Capabilities for Greater-Than-Class C LowLevel Radioactive Waste

Document Number: DOELLLW-203

Document Date: $\quad$ May 1994

Publication Status: $\quad$ Formal Report

GTCC LLW Treatment DOELLLW-203

Synopsis:

This document provides information on 26 low-level waste (LLW) and high-level waste (HLW) treatment capabilities located at Department of Energy (DOE) facilities and national laboratories. Greaterthan-Class C low-level waste (GTCC LLW) is not currently being treated; however, six of the treatment capabilities could be used to treat GTCC LLW. These include:

- The glass ceramic process

- The Waste Experimental reduction Facility (WERF) at the Idaho National Engineering Laboratory (INEL)

- The super compaction and repackaging facility

- The microwave melting and repackaging at the Rocky Flats plant (RFP)

- The vitrification plant at the Savannah River Site

- The vitrification plant at the West Valley Demonstration Project.

Specific information related to these proccsscs includes the feed stock requirements, process functions, throughput rates, limitations, and post-treatment waste forms.

Although GTCC LLW is not being treated, the DOE equivalent to Nuclear Regulatory Commission Class A, B, and C LLW plus HLW is being trcated using various processes and technologies. Of these, the following four could be feasible for treating GTCC LLW:

- Vitrification

- Cement matrix solidification

- Incineration

- Compaction. 
The study described in this document determined that facilities do exist within the DOE complex to treat GTCC LLW on a waste-stream-specific basis. However, none are currently treating GTCC LLW or its government-generated equivalent, known as special-case waste. Introducing GTCC LLW as added waste streams to operational or near operational facilities would seriously impede their activities.

Future use limitations and recommendations:

Many of the treatment technologies at DOE facilities described in this document are in the early phases of development. These facilities may have to be re-investigated after some operational time period to gain new data and insight for the technology application for treating GTCC LLW. 
Topic:

Document Title: Commercial Sector Treatment Capabilities for Greater-Than-Class C Low-Level Radioactive Waste

Document Number: DOE/LLW-183

Document Date: June 1993

Publication Status: Formal Report

Synopsis:

This report describes four commercial treatment facilities that are currently licensed and operational. Future treatment capabilities are also discussed.

Four commercial facilities that have the capability to treat greater-than-Class $\mathrm{Clow}$-level waste are discussed in this document. Each facility is fully licensed and staffed to treat LLW. Each facility is described in this document. Information for each facility includes feed stock requirements, process functions, throughput rates, treatment limitations, post-treatment waste form, and rough order-of-magnitude cost estimates.

None of the commercial facilities described in this document is licensed to treat GTCC LLW, and none has current interest or future plans for treating GTCC LLW

Future use limitations and recommendations:

None at this time. 
Topic: $\quad$ GTCC LLW Treatment

Document Title: $\quad$ Greater-Than-Class C Low-Level Radioactive Waste Treatment Technology Evaluation

Document Number: DOE/LLW-159

Document Date: January 1993

Publication Status: Formal Report (Final)

\section{Synopsis:}

This report was developed to provide the Greater-Than-Class C Low-Level Radioactive Waste Management Program with criteria and a methodology to select candidate technologies for treatment of greater-than-Class C low-level radioactive waste (GTCC LLW) destined for dedicated storage and ultimate disposal. The technology selection criteria are provided in a Lotus spreadsheet format to allow the methodology to evolve as the GTCC LLW Management Program evolves. The final disposal facility is not yet defined; therefore, the waste acceptance criteria and other facility-specific features are subject to change.

\section{Future use limitations and recommendations:}

The treatment technologies should be re-evaluated when the GTCC LLW acceptance criteria for disposal have been defined. 
Topic:

Document Title: $\quad$ Evaluation of Treatment Technologies for Greater-Than-Class C Low-Level

Document Number: DOELLLW-136

Document Date: $\quad$ October 1991

Publication Status: Formal Report (Draft) Radioactive Waste

GTCC LLW Treatment

\section{Synopsis:}

This document identifies candidate treatment technologies and integrated processes to ensure that methods are available to treat greater-than-Class C low-level radioactive waste (GTCC LLW) so that the waste is acceptable for disposal. Selection of the criteria is based on: ability to meet existing waste form disposal criteria, ability to accommodate a variety of materials found in GTCC LLW, quality of the waste form, waste form volume, and development status.

The evaluation in this document indicates that the most reasonable candidates for GTCC LLW treatment that should be pursued by the program in future efforts are ceramic melter vitrification, size reduction (plasma cutting), metal melting (plasma furnace), and cementation.

Future use limitations and recommendations:

This report was prepared by Pacific Northwest Laboratories (PNL). After PNL finished this report, the Program staff felt that the technologies presented in this document would not require further investigation at that time. This report was never published in final form. It has been replaced by later documents on this subject. 


\section{DOCUMENTS RELATED TO GTCC LLW FEE SPECIFICATION}

The documents in this section of the catalog contain information and studies relative to the fees and other charges that could be associated with the management and disposal of GTCC LLW. 
Topic: $\quad$ GTCC LLW Fee Specification

Document Title: Funding, Financial, and Accounting Issues Related to Management and Disposal of Greater-Than-Class C Low-Level Radioactive Waste

Document Number: EGG-WM-10911

Document Date: $\quad$ August 1993

Publication Status: Informal Report (Final)

Synopsis:

This document evaluates the funding, financial, and accounting issues that affect the Department of Energy's (DOE's) program for the management and disposal of greater-than-Class C low-level Waste (GTCC LLW). Along with legislative and regulatory requirements, Federal directives in these areas set the institutional framework for this program.

The information in this document indicales that, except for initial funding in the early years, general revenue funding of developmental costs for the program may not be a dependable or appropriate method for securing funding.

The document casts doubt on whether a program for addressing the current regulatory problem with sealed source management should be implemented as a subpart of the GTCC LLW program. The two efforts have some similarities, but the proposal that DOE accept hundreds or thousands of sealed sources from outside the DOE system appears distinctive enough to warrant implementation as a separate effort under a separate budget line. Moreover, Federal policies on cost recovery for services provided make it unlikely that DOE would be in a position to reduce or waive fees for providing these services to licensees who need to accept their unwanted sources.

Finally, this document notes that, under the current strategy for management and disposal of GTCC LLW, a separate DOE system-wide receipts account would enable the program to capture information about monies received for waste accepted. This information would be used in developing a fee schedule for acceptance of subsequent GTCC LLW.

\section{Future use limitations and recommendations:}

The information and conclusions in this document could be subject to revision if current GTCC LLW Management Program or sealed source management strategy changes. The information in this document includes a number of baseline assumptions that are generic to most alternative program strategies. Therefore, it should remain a useful reference document for program planning. 
Topic:

Document Title:

GTCC LLW Fee Specification

Waste Management Facilities Cost Information Report for Greater-Than-Class C and DOE Equivalent Special-Case Waste

Document Number: EGG-WM-10701

Document Date: July 1993

Publication Status: Informal Report (Final)

\section{Synopsis:}

This report contains preconceptual designs and planning level life-cycle cost (PLCC) estimates for treatment, storage, and disposal facilities needed for managing greater-than-Class $\mathrm{C}$ low-level radioactive waste (GTCC LLW) and Department of Energy (DOE) equivalent waste. The report contains information on 16 facilities (referred to as cost modules). These facilities are treatment facility front-end and back-end support functions (administration support, and receiving, preparation, and shipping cost modules); seven treatment concepts (incineration, metal melting, shredding/compaction, solidification, vitrification, metal sizing and decontamination, and wet/air oxidation cost modules); two storage concepts (enclosed vault and silo); disposal concepts (shallow-land, enginecred shallow-land, intermediate depth, and deep geological cost modules). Data in this report allow the user to develop PLCC estimates for various waste management options. A procedure to guide DOE and its contractor personnel in the use of estimating data is also included in this report.

Future use limitations and recommendations:

For ease of application, facility description and PLCC estimates related to some of the modules contained in previous Waste Management cost information reports (EGG-WTD-10443 and EGG-WM10708) are repeated here. The reader should note that, when repeating previous modules, they have been either resized for adoption to GTCC and DOE equivalent special-case waste or updated to incorporate the latest cost data. 
Topic: $\quad$ GTCC LLW Fee Specification

Document Title: $\quad$ Waste Management Facilities Cost Information Estimating Data for GreaterThan-Class C and DOE Equivalent Special-Case Waste

Document Number: EGG-WM-10708

Document Date: July 1993

Publication Status: Informal Report

\section{Synopsis:}

This report contains preliminary information related to preconceptual designs and planning level life-cycle cost (PLCC) estimates for treatment, storage, and disposal facilities needed for managing greaterthan-Class C low-level radioactive waste (GTCC LLW) and Department of Energy (DOE) equivalent waste. The report contains information on 16 facilities (referred to as cost modules). These facilities are treatment facility front-end and back-end support functions (administration support, and receiving, preparation, and shipping cost modules); seven treatment concepts (incineration, metal melting, shredding/compaction, solidification, vitrification, metal sizing and decontamination, and wet/air oxidation cost modules); two storage concepts (enclosed vault and silo); disposal concepts (shallow-land, engineered shallow-land, intermediate depth, and deep geological cost modules).

Data in this report was further refined in the report EGG-WM-10701 and provides suuporting data used in that report.

\section{Future use limitations and recommendations:}

The cost information contained in this document was based on the best current data available. As with all financial-related information changes in Federal policy, inflation and other factors can have a significant impact on the cost information contained in this document. It is important to note that the program only paid a small portion of the costs associated with this report. 
Topic:

Document Title:

Document Number:

Document Date:

Publication Status:
GTCC LLW Fee Specification

Proposed Fee Schedule for GTCC LLW Requiring Interim Storage
DOELLLW-169

March 1993

Synopsis:

This document develops and recommends a waste acceptance fee for interim storage of greater-thanClass C Low-Level Radioactive Waste (GTCC LLW) in a Department of Energy (DOE) facility. The DOE plans to provide interim storage for limited amounts of GTCC LLW, specifically sealed radiation sources, which are judged by the regulatory agency to constitute a threat to public health and safety. A portion of the costs associated with this storage would be recovered by charging users a waste acceptance fee.

This document provides current fee information, specific to the expected characteristics of sealed sources, for commercial disposal of Class C LLW. Fees charged by commercial disposal facilities have been developed and refined over the years based on actual costs to the companies for the materials, equipment, labor, and overhead involved in inspecting, removing, repackaging, and disposing of radioactive materials. In most cases, waste generators have been able to accept these fees as a fair and reasonable cost of doing business. However, these fees (a) include an unknown percentage for corporate profits, which should not be a part of DOE's waste acceptance fees, and (b) reflect the costs for near-surface disposal, which are probably lower than storage and disposal costs that DOE will incur in the overall management of these wastes.

The information in this report indicates that a fee of $\$ 1000 /$ source would be a starting base fee. Additional options could bring the maximum cost per source to $\$ 4,124$.

Future use limitations and recommendations:

The cost information contained in this document was based on the best current data available. As with all financial-related information, changes in Federal policy, inflation and other factors can have a significant impact on the cost information contained in this document. 


\section{DOCUMENTS RELATED TO GTCC LLW DISPOSAL}

The documents in this section of the catalog contain information and studies related to the disposal of GTCC LLW. 
Topic:

Document Title: $\quad$ Social and Institutional Evaluation Report for Greater-Than-Class C Low-Level

Document Number: DOELLW-186

Document Date: July 1993

Publication Status: Formal Report (currently being finalized) Radioactive Waste Disposal

GTCC LLW Disposal

\section{Synopsis:}

This report identifies and characterizes social and institutional issues that would be relevant to siting, licensing, construction, closure, and post closure of a greater-than-Class Clow-level waste (GTCC LLW) disposal facility. A historical perspective of high-level waste (HLW) and LLW disposal programs is provided as an overview of radioactive waste disposal and to support the recommendations and conclusions of the report. A characterization of each issue is provided to establish the basis for further evaluations. Where applicable, the regulatory requirements of $10 \mathrm{CFR} 60$ and 61 are incorporated in the issue characterizations. The issues are used to compare surface, intermediate depth, and deep geologic disposal alternatives.

This report recommends five categories in which to address the social and institutional issues throughout the GTCC waste disposal program. These categories include:

- $\quad$ Address Issue Through Siting Criteria

- Develop an Impact Alleviation Plan

- Develop a Public Education and Involvement Program

- Use Good Management Practices

- Establishment and Institutional Framework.

\section{Future use limitations and recommendations:}

This report is based on the assumption that a new dedicated GTCC LLW disposal facility will be developed, rather than the currently favored co-disposal scenarios. 
Topic:

Document Title: Economics Evaluation of Technically Feasible Systems for the Disposal of Greater-Than-Class C Low-Level Radioactive Waste

Document Number: RAE-9208/1-3 (Published under subcontract to Rogers and Associates)

Document Date: June 1993

Publication Status: Letter Report

Synopsis:

Development of permanent disposal capacity for greater-than-Class $\mathrm{Clow}$-level radioactive waste (GTCC LLW) requires the evaluation of potential disposal concepts in terms of technical feasibility, economics, and institutional concerns. Previously developed order-of-magnitude cost estimates were refined and the costs projected over time to account for the time value of money.

The technical performance for each disposal concept was compared to its estimated constant dollar, present value, and current dollar costs. This identified the cost-effective disposal concepts. The arid disposal concepts, which are the most cost effective, are the near-surface modular concrete canister and the intermediate-depth drilled hole. The most cost-effective disposal concepts for the humid site is the drilled hole concept at either the intermediate depth or deep geologic disposal horizon.

Order-of-magnitude costs for the recommended arid system range for $\$ 191,000,000$ and $\$ 59,000 / \mathrm{m}^{3}$ to $\$ 293,000,000$ and $\$ 90,000 / \mathrm{m}^{3}$. The recommended disposal system at a humid site makes use of only intermediate depth or deep geologic disposal concepts; wither drilled holes or mined cavities could be used. Order-of-magnitude costs for the recommended humid system range from $\$ 273,000,000$ and $\$ 84,000 / \mathrm{m}^{3}$ to $\$ 396,000,000$ and $\$ 122,000 / \mathrm{m}^{3}$.

Future use limitations and recommendations:

This report is based on the assumption that a new dedicated GTCC LLW disposal facility will be developed, rather than the currently favored co-disposal scenarios. 
Topic:

Document Title

Document Number:

Document Date:

Publication Status:
GTCC LLW Disposal

Technically Feasible Systems for the Disposal of GTCC LLW

\section{Synopsis:}

Development of permanent disposal capacity for greater-than-Class C low-level waste (GTCC LLW) requires the evaluation of potential disposal concepts in terms of technical feasibility, economics, and institutional concerns. Data from previous studies identified 13 potential disposal concepts that characterized the volumes and types of GTCC LLW along with newly developed data on concept designs and hypothetical sites to evaluate each concept's performance over 100,000 years.

Performance was evaluated in terms of confinement and intrusion. Specific performance measures for which deterministic and probabilistic calculations were performed are:

- Confinement

$\begin{array}{ll}- & \text { Total releases } \\ \text { - } & \text { Groundwater concentrations } \\ \text { - } & \text { Radiation doses }\end{array}$

- Intrusion

$$
\begin{array}{ll}
- & \text { Potential intrusion crents } \\
\text { - } & \text { Intrusion consequences. }
\end{array}
$$

Order of magnitude costs were also developed as a preliminary step in the conduct of a separate economic analysis.

It has been determined that there are two types technically feasible disposal systems. The recommended system at an arid site makes used of either the near surface modular concrete canisters concepts, the intermediate depth drilled holes concepts or thc intermediate depth mined cavity concept. 
Future use limitations and recommendations:

The evaluations in this report assume a ncw dedicated GTCC LLW disposal facility rather than the current preferred co-disposal scenarios. 
Topic:

Document Title: Identification of Polential Intermediate Depth and Deep Geologic Disposal Concepts for Greater-Than-Class C Low-Level Radioactive Waste

Document Number: DOELLW-104a

Document Date: June 1991

Publication Status: Formal Report (Draft)

\section{Synopsis:}

This document discusses the evaluation of intermediate depth and deep geologic disposal options for the disposal of GTCC LLW. The objective is to identify a set of disposal options for detailed evaluation.

The first step in the evaluation of intermediate depth and deep geologic disposal options was to survey previously defined disposal concepts and identify those that would be appropriate for intermediate depth or deep geologic facilities. The engineered aspects of the disposal concepts were then reviewed and key elements identified.

The next step was to identify the regulatory requirements that an acceptable disposal concept would be expected to satisfy. After the relevant regulatory requirements were identified, they were correlated with the key disposal technology elements to determine general categories of disposal concept elements that would comprise an acceptable intermediate depth or deep geologic disposal concept.

The following disposal concept elements were identified:

- Construction configurations:

$\begin{array}{ll}- & \text { Mined cavity } \\ - & \text { Drilled hole } \\ - & \text { Man-made void } \\ - & \text { Open excavation }\end{array}$

- Barriers:

$\begin{array}{ll}- & \text { Vault } \\ - & \text { Canister } \\ - & \text { Backfill }\end{array}$

- Waste Packages: 
- Emplacement Configurations:

- Layered placement

- Borehole placement.

A methodology was developed for systcmatically screening the set of disposal concepts. The disposal concepts were evaluated and scored according to the screening criteria. The screening.criteria were:

- Research and development

- Testing and development

- Environmental impact

- Institutional impact

- Technical complexity

- Regulatory readiness

- Regulatory acceptability.

Scores were then evaluated and disposal concepts ranked. Based on this ranking, ten disposal concepts are recommended for further detailed evaluation.

Future use limitations and recommendations:

The preliminary screening in this report provided the bases for more rigorous evaluations in a later document (DOELLLW-176). 
Topic:

Document Title: $\quad$ Technical Evaluation of Near-Surface Disposal Systems for Greater-Than-Class C Low-Level Radioacive Waste-Preliminary Performance Assessment

Document Number: DOELLW-104b

Document Date: June 1991

Publication Status: Formal Report (Draft)

Synopsis:

This document describes the first and second phase of a three-phased approach to a technical evaluation of disposal concepts for greater-than-Class C low-level waste (GTCC LLW). The three phases are initial screening, preliminary performance assessments (PA), detailed performance assessments.

The objective of the screening phase is to recommend potential technically feasible disposal concepts for further evaluation. The objective of the preliminary PA is to identify contaminants of concern (radionuclides that represent a substantial fraction of estimatcd doses), and to screen the number of potential disposal systems into a set that will be evaluated in a detailed PA.

The initial screening resulted in the sclection of five near-surface disposal concepts. These concepts were then grouped into two major categorics for the preliminary PA: GTCC LLW disposal in a near surface facility where no concrete structure surrounds the waste containers, and GTCC LLW disposal in a near surface facility where waste containers are place in a concrete structure. These categories were evaluated for potential arid and humid waste disposal sitcs.

The calculations and modeling used to perform the preliminary PA indicate that all of the disposal concepts are susceptible to pathway dependent migration, especially the groundwater pathway. In addition, waste disposal should not be sited near surface water. The addition of a concrete vault increases migration times to tens of thousands of years longer than sites with no concrete containment.

Future use limitations and recommendations:

The preliminary screening in this report provided the bases for more rigorous evaluations in a later document (DOELLW-176). 
Topic:

Document Title:

GTCC LLW Disposal

LLW Management Handbook: Planning for Greater Confinement Disposal, Volume II: Appendices

Document Number: DOELLW-58T

Document Date: September 1986

Publication Status: Formal Report

Synopsis:

This document contains appendix information for the report DOELLW-53T. Appendix information includes:

- Appendix A: Above grade Confinement

- Appendix B: Below grade Confinement

- Appendix C: Waste-Form and Container Confinement

- Appendix D: Methodology

- Appendix E: Waste Classification and Characteristics.

These appendices contain data, information, definitions, process, descriptions, source term information, and other references used to detail data in the rcport DOELLW-53T.

Future use limitations and recommendations:

This report was prepared during an early planning stage for GTCC LLW disposal; thus it may not be fully compatible with current program strategics and requirements. 
Topic: $\quad$ GTCC LLW Disposal

Document Title: $\quad$ LLWHandbook Series: Planning for Greater Confinement Disposal, Volume I: Alternatives and Methods

Document Number: DOELLW-53T

Document Date: August 1986

Publication Status: Formal Report

Synopsis:

This document contains a description and discussion of ten disposal technologies and of planning methods for selecting and implementing an optimum disposal technology for any radioactive waste stream. The intent is to present a spectrum of technologies that can be matched to the different confinement requirements for different waste streams ranging from LLW where shallow-land burial might be sufficient to LLW for which underground disposal may be needed.

This document evaluated disposal alternatives to include above grade confinement, below grade confinement, and waste form and container confinement. It describes:

- Planning sequence and methodology used to perform the evaluation

- Associated detriments and costs for these alternatives

- Potential radiological pathways and associated doses

- Properties and acceptability of different waste forms

- Regulatory and other requirements.

Methods are described for deriving a confinement factor that provides a quantitative characterization of the confinement capabilities of a site and disposal technology. This factor is used to determine radiological detriments and to derive waste acceptance critcria. A key feature of the methodology is that performance requirements and selection procedures are derived in a quantitative manner with a single objective in mind, protection of public health and safety.

Future use limitations and recommendations:

This report was prepared during an early planning stage for GTCC LLW disposal; thus it may not be fully compatible with current program stratcgies and requirements. 
Topic:

Document Title: Analysis of Alternatives of Greater Confinement Disposal

Document Number: DOELLLW-31T

Document Date: November 1985

Publication Status: Formal Report (Final)

Synopsis:

This document describes a comparative method for evaluating alternatives for greater-confinement disposal (GCD) of loẉ-level radioactive wastc (LLW). Nine GCD disposal alternatives were evaluated. These are:

- Shallow-land burial (SLB)

- Deep geologic repository

- Deep trench burial

- Improved waste form

- Engineered structures

- Boreholes

- Hydrofracture

- Shallow-land repository.

The alternatives are ranked based on a ranking parameter (RP) $[R P$ equals cost $\mathbb{O}$ in dollars plus health ( $\mathrm{H})$ ( $\mathrm{H}$ risk converted to dollars)], which is derived from benefitlcostlrisk analysis. Costs are developed for a GCD facility that is co-located with a conventional shallow-land burial facility. The GCD facility is estimated to have a capacity of $10,000 \mathrm{~m}^{3}$. Risks are based on a pathway analysis for estimating the dose to individuals resulting from waste placed in a GCD facility.

Application of the method, using a generic analysis based on representative waste streams of intermediate-activity and high-activity LLW that would require GCD, indicates that all alternatives, except SLB, meet the performance objectives ( $500 \mathrm{mrem} / \mathrm{yr}$ whole-body dose to onsite intruders and $25 \mathrm{mrem} / \mathrm{yr}$ whole-body dose to members of the public from releases to the environment). 
Future use limitations and recommendations:

This report was prepared during an early planning stage for GTCC LLW disposal; thus it may not be fully compatible with current program strategies and requirements. 


\section{MISCELLANEOUS DOCUMENTS}

This section of the catalog describes documents that do not typically fit into one of the previous sections. These documents include those related to studies conducted related to co-management, co-storage, and co-disposal of greater-than-Class C low-lcvel waste (GTCC LLW) with Department of Energy (DOE) special-case waste (SCW). Additional documents include those related specifically to issues related to the management, storage, and disposal of sealed sources.

\subsection{Documents Related to GTCC LLW/Special-Case Waste}

This section of the catalog contains documents related to the management, storage, and disposal of GTCC LLW with DOE SCW. SCW is DOE-generated waste that does not fit into current DOE management plans, such as high-level waste (HLW), transuranic waste (TRU), and low-level waste (LLW). Since the physical form and radionuclide content of many DOE SCW forms are similar to GTCC LLW, the GTCC LLW Management Program has prepared several documents related to GTCC/SCW issues. 
Topic:

Document Title: $\quad$ Potential Co-Disposal of Greater-Than-Class C Low-Level Radioactive Waste with Department of Energy Special Case Waste

Document Number: DOELLW-213

Document Date: $\quad$ September 1994

Publication Status: Formal Report (Final Draft)

GTCC LLW/DOE Special Case Waste

Synopsis:

This document evaluates the feasibility of co-disposing greater-than-Class $\mathrm{C}$ low-level radioactive waste (GTCC LLW) with Department of Energy (DOE) special-case waste (SCW). This document examines the co-disposal issues such as:

- Regulatory concerns

- Technical feasibility

- Economics.

The document also discusses the similarities between GTCC LLW and DOE SCW. In addition, this document identifies several disposal systems within the DOE system that could be used to co-dispose of GTCC LLW and SCW.

The following recommendations are given in this document in order to continue research into the feasibility of, and benefits for, integrating the management and disposal of GTCC LLW with DOE SCW:

- Develop and implement a DOE complex-wide management strategy for SCW

- Incorporate a complex-wide nomenclature for SCW and GTCC LLW consistent with Federal regulations and DOE orders.

- Develop and implement a complex-wide DOE SCW characterization program

- Continue to identify and study options for the management and disposal of GTCC LLW and SCW.

Combining the management and disposal of these two waste types will increase safety and efficiency while decreasing the cost by avoiding duplication of effort. 
Future use limitations and recommendations:

It is important to note that disposal licensed by the Nuclear Regulatory Commission (NRC) is required for GTCC LLW and not required for DOE SCW. This could bring about a need for some sort of regulatory change, whether for GTCC LLW or SCW, in order to make co-disposal feasible. 
Topic:

Document Title:

Document Number:

Document Date: $\quad$ May 1994

Publication Status: Formal Report (Draft)

\section{Synopsis:}

GTCC LLW/DOE Special Case Waste

Technical Survey of DOE Programs and Facilities Applicable to the Co-Storage of Commercial GTCC LLW and DOE SCW

This document presents information on those Department of Energy (DOE) management programs and facilities, existing and planned, that are or could be capable of providing storage for DOE special-case waste (SCW) until a disposal option is available. Major emphasis is given to the possibility of storing commercial greater-than-Class C low-level waste (GTCC LLW) in concert with DOE SCW as well as with other waste types. In addition to this primary issue, the report gives an in-depth background on SCW, GTCC LLW and discusses their similarities.

The document includes information provided by six DOE operations offices and their contractors in response to a questionnaire survey. Also, additional information was acquired through the Waste Stream and Technology Data System, which contains data on DOE-designated radioactive treatment, storage, and disposal (TSD) facilities throughout the DOE complex.

This document concludes:

- Currently a DOE complex-wide comprehensive strategy does not exist for managing SCW. Only Hanford and the INEL had opcrational SCW management programs.

- Most SCW in the DOE system is being held at the site of generation. Although these are not designated storage facilities as defined for this report, they do comply with DOE orders and regulations.

- Designated storage facilities capable of managing SCW and GTCC LLW currently exist.

Future use limitations and recommendations:

This document should provide a useful reference should the co-storage of SCW and GTCC LLW become policy. 
Topic:

Document Title: $\quad$ Greater-Than-Class C Low-Level Radioactive Waste Special Case Wastes (SCW) at the Idaho National Laboratory (INEL): Vol. 1: Inventory and Characteristics

Document Number: EGG-WM-10905

Document Date: $\quad$ September 1993

Publication Status: Informal Report

Synopsis:

This document lists, classifies, and characterizes special-case waste (SCW) at the Idaho National Engineering Laboratory. SCWs are radioactive wastes that typically do not fit into current U.S. Department of Energy (DOE) management plans for final treatment or disposal. The waste forms include fuel and fuel debris, reactor core components, sealed sources, special experiment test apparatus, process wastes, commercial wastes for which DOE has acceptcd title, and other wastes that cannot be disposed of at this time. Also characterized in this report are commercial wastes that are above the Class $\mathrm{C}$ regulatory limits for near-surface disposal. DOE has, by contractual agreement, agreed to store these wastes to protect public health and safety. These wastes are referred to as DOE-Held greater-than-Class C low-level wastes (GTCC LLW). SCW and GTCC LLW pose potential problems to generators, handlers, and disposal facility operators because their radioactivity levels are high, or as a result of their physical form or other characteristics. These wastes may require special management and disposal. This report presents a history of SCW and GTCC LLW at the Idaho National Engineering Laboratory (INEL), describes differences between SCW and GTCC LLW at the INEL facility, and makes recommendations for the characterization of SCW and co-management of some SCW and GTCC LLW forms.

Future use limitations and recommendations:

This document was revised and updated in 1994 and assigned a new report number. Funding for this document was provided by the INEL SCW waste type manager. This document was used to provide information for follow on documents that were prepared for the program. 
Topic: $\quad$ DOE Special Case Waste

Document Title: $\quad$ DOE Special Case Waste and DOE-Held Greater-Than-Class C Waste at the INEL Vol. 2: Management Strategies

Document Number: EGG-WM-10905

Document Date: September 1993

Publication Status: Informal Report

\section{Synopsis:}

This document recommends preliminary strategies for management of special-case waste (SCW) and greater-than-Class C low-level waste (GTCC LLW) at the Idaho National Engineering Laboratory (INEL). SCW is defined as having been generated by the U.S. Department of Energy (DOE) or as titled radioactive waste that does not fit into typical management plans developed for the major radioactive waste types:

transuranic (TRU), low-level radioactive waste (LLW), or high-level radioactive waste (HLW). GTCC LLW is radioactive waste that is generated by the licensee's of the Nuclear Regulatory Commission (NRC) or by an Agreement State, and that exceeds the Class $\mathrm{C}$ limits defined in Title 10, Code of Federal Regulations, Part 61 (10 CFR 61). Federal law requires that DOE ensure safe disposal of GTCC LLW in a disposal facility licensed by the NRC. Some commercially gencrated wastes that exceed Class $\mathrm{Cl}$ limits are currently stored at the INEL.

The information in this document indicates that it is feasible, and may be advantageous, to co-manage GTCC LLW with DOE SCW.

Future use limitations and recommendations:

None at this time. 
Topic:

Document Title: $\quad$ DOE Special Case Waste and Greater-Than-Class C Low-Level Radioactive Waste at the INEL: Vol. 3: Feasibility of Integrating Management and Disposition on a National Basis

Document Number: EGG-WM-10905

Document Date: $\quad$ October 1993

Publication Status: Informal Report

Synopsis:

This report evaluates the feasibility of integrating the management and disposition of greater-than-Class C low-level waste (GTCC LLW) with Department of Energy (DOE) special case waste (SCW) under one system. SCW is defined as DOE-generated or as titled radioactive waste that does not fit into typical management plans developed for the major radioactive waste types: transuranic (TRU), low-level radioactive waste (LLW), or high-level radioactive waste (HLW). GTCC LLW is radioactive waste that is generated by Nuclear Regulatory Commission (NRC) licensees or Agreement States, and that exceeds the Class $C$ limits defined in 10 CFR 61. Federal law requires that DOE dispose of GTCC LLW in an NRC-licensed disposal facility.

The information presented in this report indicates that it is feasible, and may be desirable, to integrate the management of GTCC LLW with DOE SCW.

Future use limitations and recommendations:

None at this time. 


\subsection{Documents Related to GTCC LLW Sealed Sources}

This section of the catalog contains information and studies related to characterizing and managing sealed sources. 
Topic:

Document Title: - Characterization of Potential Greater-Than-Class C Sealed Sources Volume 1: Sealed Sources Held by Specific Licensees

Document Number: DOE/LLW-163

Document Date: $\quad$ August 1994

Publication Status:

\section{Synopsis:}

This report, the first of three volumes investigating sealed sources that are or may be greater-than-Class C (GTCC) low-level waste (LLW), presents the results of two surveys that estimate the number, volume, and activity of sealed sources held by specific licensees, and for which the U.S. Department of Energy (DOE) may have eventual disposal responsibility.

This document describes the historical background information relating to regulatory control of GTCC sealed sources and describes past estimates of numbers of GTCC sealed sources. Two surveys were conducted [one by DOE and one by the Nuclear Regulatory Commission (NRC)]. Data from these surveys were used to estimate the total number of GTCC sealed sources. The methods for conducting the surveys and for estimating the number of sealed sources are described in this document.

The data and information in this document divide the sealed sources into nine separate device types:

- Calibration

- $\quad$ Media

- Well logging

- Portable gauge

- Irradiation

- $\quad$ Fixed gauge

- General neutron applications

- $\quad \mathrm{X}$-ray fluorescence

- Other.

The majority of these sources is in fixed and portable gauges, with well logging devices accounting for a significant portion of the total volume. ${ }^{137} \mathrm{Cs}$ is the most frequently encountered radionuclide. 
Future use limitations and recommendations:

The volumes and activities reported in this document are based on survey results statistically extrapolated to the total population. If new or more accurate information is obtained, there could be a significant impact on the data presented in this document. 
Topic:

Document Title: $\quad$.Characterization of Greater-Than-Class C Sealed Sources Volume 2: Sealed Source Characterization and Future Production

Document Number: DOE/LLW-163

Document Date: $\quad$ August 1994

Publication Status: Formal Report (Final)

Synopsis:

This report, the second of three volumes investigating sealed sources that may eventually become greater-than-Class C (GTCC) low-level radioactive waste (LLW), characterizes sealed sources and estimates current and future production rates of sealed sources sold to specific licensees. Information on which to base the production estimates was obtained from the Nuclear Regulatory Commission's Sealed Source and Device Database and by contacting sealed source and device manufacturers.

This document

- Describes the types of sealed sources

- Describes the general construction of sealed sources

- Makes future projections of scaled sources to the year 2035

- Describes the database used to make the projections.

The database projections took into account such factors as source recycling, operational lifetime, and political and economic factors.

It is estimated that there will be between 4,700 and 11,500 sealed sources produced annually in the United States. With source recycling and other factors there could be as many as 44,000 sealed sources that exceed Class C limits and are therefore in need of disposal in the year 2035.

\section{Future use limitations and recommendations:}

The volumes and activities reported in this document are based on survey results statistically extrapolated to the total population. If new or more accurate information is obtained, there could be a significant impact on the data presented in this document. 
Topic:

GTCC LLW Sealed Sources

Document Title: $\quad$ Characterization of Greater-Than-Class C Low-Level Radioactive Waste Sealed Sources Volume 3: Sealed Sources Held by General Licensees

Document Number: DOE/LLW-163

Document Date: $\quad$ August 1994

Publication Status: Formal Report (Final)

Synopsis:

This is the third in a three-volume series characterizing the population of sealed sources that may become greater-than-Class C low-level waste (GTCC LLW). In this volume, those sources possessed by general licensees are discussed.

General licensed devices may contain scaled sources with significant amounts of radioactive material. However, the devices are designed to be safe without special knowledge or radiological safety practices. Devices containing ${ }^{241} \mathrm{Am}$ or ${ }^{244} \mathrm{Cm}$ are most likely to become GTCC LLW.

This study estimates that about 16,000 GTCC devices are held by general licensees; 15,000 of these contain ${ }^{241} \mathrm{Am}$ and 1,000 contain ${ }^{244} \mathrm{Cm}$. Additionally, this study estimates that about 1,600 GTCC devices are sold to general licensees each year. However, because there is insufficient information on general licensees in Agreement States, these estimates are uncertain.

\section{Future use limitations and recommendations:}

The volumes and activities reported in this document are based on survey results statistically extrapolated to the total population. If new or more accurate information is obtained, there could be a significant impact on the data presented in this document. 